\title{
Heterogeneity of Human Platelets
}

\author{
V. DIFFERENCES IN GLYCOLYTIC AND RELATED ENZYMES WITH \\ POSSIBLE RELATION TO PLATELET AGE
}

\author{
Simon Karpatkin and Nathan Strick \\ From the Department of Medicine, New York University Medical School, \\ New York 10016
}

A B S T R A C T Human platelets were separated by density-centrifugation into heavy and light populations. Heavy platelets have an average volume approximately twofold greater than light platelets, and have previously been shown to be young platelets.

All 11 enzymes of the Embden-Meyerhof pathway plus the five related enzymes: phosphoglucomutase, glucose-6-P dehydrogenase, 6-P-gluconic dehydrogenase, $\alpha$-glycerol-P dehydrogenase, and glutathione reductase (TPNH) were examined in cell lysates from total, heavy, and light platelet populations. Apparent $K m$ for individual enzymes were measured in a total platelet population. Empirical $\mathrm{V}_{\max }$ of the individual enzymes were measured in total, heavy, and light platelet populations. The three apparent rate-limiting enzymes for glycolysis were hexokinase, phosphofructokinase, and glyceraldehyde-3-P dehydrogenase.

Heavy platelets contained approximately twofold greater enzyme activity (per gram wet weight) than light platelets for 7 of the 16 enzymes measured: hexokinase, phosphohexoisomerase, phosphofructokinase, glyceraldehyde-3-P dehydrogenase, phosphoglycerokinase, lactic dehydrogenase, and phosphoglucomutase. Heavy platelets also contained 1.9-fold greater reduced glutathione (GSH), 1.7-fold greater DPNH, and 1.2fold greater TPNH than light platelets. Heavy platelets contained 1.8-fold less lipid peroxidation products (malonyl aldehyde equivalents) than light platelets and were 2.4-fold more resistant to lipid peroxidation catalyzed by $0.1 \mathrm{~mm} \mathrm{FeCl}_{3}$.

Sterile incubation of heavy platelets, in vitro for 17 $\mathrm{hr}$, resulted in a significant loss of enzyme activity for

Dr. Karpatkin is a Career Scientist of the Health Research Council of the City of New York (1-459).

Received for publication 8 October 1971 and in revised form 13 December 1971. the "elevated" seven enzymes when compared with the remainder. Reducing agents such as GSH (0.1 $\mathrm{mm})$, ascorbic acid (0.1 $\mathrm{mm}$ ), and dithiothreitol (0.01 $\mathrm{mm})$, when added to the incubation mixture, significantly reduced the in vitro loss of activity. In vitro incubation was also associated with a significant loss of GSH and DPNH and a 1.8-fold increase in lipid peroxidation products.

\section{INTRODUCTION}

Human platelets have a significant aerobic glycolytic metabolism (1-3) and are dependent to a large extent upon the Embden-Meyerhof pathway for their energy requirement. Recently, they have been shown to be heterogeneous and can be separated into two extreme density populations, each representing approximately $15 \%$ of the total platelet population (4). The heavy platelet population has an average platelet volume which is approximately twofold greater than the light platelet population.

The large heavy platelet, when compared with the smaller lighter platelet, has been shown to have a greater glycogen, adenine nucleotide, and orthophosphate content (4); to have a greater rate of glycogenolysis, glycolysis (4), glycogenesis, glyconeogenesis (5), protein synthesis (4); and to have a greater resistance to osmotic shock (i.e., maintenance of ionic gradients [4]).

The large heavy platelet, when compared with the smaller lighter platelet, has also been shown to have a greater functional capacity with respect to more rapid aggregation with such physiologic aggregating agents as: adenosine diphosphate (ADP), thrombin, and epinephrine; associated with a greater release of adenine 
nucleotide and platelet factor 4 , an antiheparin agent (6).

Cellular kinetic data in animals (4) as well as in humans (7) have indicated that the large heavy platelet is a young platelet and have suggested that the large heavy platelet becomes a smaller lighter platelet with age.

In the present report, the activity of glycolytic and related enzymes of these two platelet populations, as well as of the total platelet population, have been examined. The apparent $K_{m},{ }^{1}$ empirical $\mathrm{V}_{\max }$, and ratelimiting enzymes of the total platelet population have been determined. The empirical $\mathrm{V}_{\max }$ of the individual enzymes have been compared in heavy and light platelet populations. A significantly greater enzyme activity was found in the heavy platelet population for certain rate-limiting as well as other enzymes. Incubation experiments with intact heavy platelets were employed to compare in vitro enzyme lability with the $V_{\max }$ enzyme differences found between heavy and light platelet populations in vivo. Enzyme lability was assessed with regard to protection by reducing agents, reductive capacity of the platelet, and resistance to lipid peroxidation.

\section{METHODS}

Preparation of washed platelets. Human platelets were obtained, collected, and processed as described previously (4). The washed platelets were suspended in a human Ringer solution (8) and separated into heavy and light platelet populations as described previously (4).

Separation of platelets into heavy and light populations. Briefly, this entails layering of $6-10 \mathrm{ml}$ of a 7-10\% platelet suspension of platelets, washed at $4^{\circ} \mathrm{C}$, over $0.5 \mathrm{ml}$ of a fixed density oil mixture. Two fixed density mixtures with a sp $\mathrm{gr}$ of 1.032 and 1.042 , respectively, are employed. Platelets remaining on the surface of the lower sp gr mixture $(<1.032)$ and platelets sedimenting to the bottom of the heavier sp $\mathrm{gr}$ mixture $(>1.042)$ were harvested.

Previous control experiments revealed that passage of platelets through this oil mixture had no discernible effect on platelet adenine nucleotide content, lactate production, or glucose uptake (4). Neither was there any effect on the enzyme activity measured in the present report.

Extraction procedure for enzyme determinations. All operations were performed at $0-4^{\circ} \mathrm{C}$ unless otherwise noted. The separated heavy and light platelet populations were washed once in Human Ringer-0.1 mM ethylenediaminetetraacetate (EDTA), approximately $20 \mathrm{vol}$ of wash to $1 \mathrm{vol}$ of platelets, and then processed for extraction. Two extraction procedures were employed: (a) Freeze-grinding. A platelet pellet was obtained by centrifugation in a plastic tube at $3000 \mathrm{~g}$ for $15 \mathrm{~min}$. The platelet pellet was frozen by completely immersing the plastic tube in liquid nitrogen, $-196^{\circ} \mathrm{C}$. The tube was then cracked open and the frozen pellet ground to a fine powder with cold mortar and pestle

${ }^{1}$ Abbreviations used in this paper: DPNH, diphosphopyridine nucleotide; GSH, reduced glutathione; $K_{m}, \mathrm{Mi}$ chaelis constant; TPNH, triphosphopyridine nucleotide; $\mathrm{V}_{\max }$, maximum velocity. containing $30 \mathrm{mg}$ of sea sand. The fine powder was extracted in $3 \mathrm{vol} / \mathrm{g}$ wet weight (or platelet volume) of $50 \mathrm{~mm}$ tris buffer, $\mathrm{pH} 7.5,5 \mathrm{~mm}$ EDTA, $5 \mathrm{~mm}$ mercaptoethanol. This mixture was allowed to thaw to $4^{\circ} \mathrm{C}$, with grinding and then centrifuged at $4000 \mathrm{~g}$ for $30 \mathrm{~min}$. The sediment was discarded and the supernate designated " $4000 \mathrm{~g}$ homogenate." A portion of this homogenate was then recentrifuged at $105,000 \mathrm{~g}$ for $60 \mathrm{~min}$ in a Beckman L2 ultracentrifuge (Beckman Instruments, Inc., Fullerton, Calif.). The sediment was suspended in its original volume of the buffer extractant with a Dounce homogenizer and designated "particulate fraction." The supernate was designated, " $105,000 \mathrm{~g}$ supernate." (b) Ultrasonic disruption. A platelet pellet was obtained as above, and suspended in 3 vol per platelet volume of human Ringer solution containing $5 \mathrm{~mm}$ EDTA, $5 \mathrm{~mm}$ mercaptoethanol, $\mathrm{pH}$ adjusted to 7.5. This suspension was sonicated at maximal intensity at $4^{\circ} \mathrm{C}$ with a Bronwill Biosonik sonicator microprobe (Bronwill Scientific, Inc., Rochester, N. Y.) for two 10 -sec intervals. This disrupted cellular suspension was then separated into a $4000 \mathrm{~g}$ homogenate, $105,000 \mathrm{~g}$ supernate, and $105,000 \mathrm{~g}$ particulate fraction, as above.

Enzymatic assays. Enzymatic assays employed classical techniques for coupling of enzymatic reactions to pyridine nucleotide oxidation-reduction changes at $340 \mathrm{~m} \mu$ and $30^{\circ} \mathrm{C}$ ( Table I). A Gilford power supply and photo-cell (Gilford Instrument Laboratories, Inc., Oberlin, Ohio), Beckman spectral system and Honeywell recorder (Honeywell, Inc., Denver, Colo.) were employed to measure initial enzyme rates. These were linear with time and "extract" concentration, and were zero in the absence of substrate (s). Optimal dilutions for concentration-dependent linearity were made with the tris buffer extractant mentioned and are given in Tables IA and $B$. Enzyme rates were assayed in microcuvettes of $0.5 \mathrm{ml}$ volume in $50 \mathrm{~mm}$ tris buffer, $5 \mathrm{~mm}$ mercaptoethanol pH 7.5 at $30^{\circ} \mathrm{C}$. All rates were assayed in triplicate, employing 10,20 , and $30-\mu 1$ portions of tissue extract.

Control experiments revealed no significant differences between enzyme activity extracted from washed platelets when compared with platelets extracted immediately after their sedimentation from plasma. The following enzymes were found to be labile (with the two extraction conditions employed) if not assayed within $2 \mathrm{hr}$ after extraction: phosphofructokinase, glyceraldehyde-3-P dehydrogenase, phosphoglucomutase, and phosphoglyceromutase. The remainder were measured the next morning, after storage at $4^{\circ} \mathrm{C}$, within a time interval of $<20 \mathrm{hr}$. These manipulations provided enzyme rates which are comparable with enzyme rates obtained immediately after extraction.

Reduced pyridine nucleotide and glutathione measurements. DPNH and TPNH were assayed spectrophotometrically by the methods of Ciotti and Kaplan (9), employing alcohol dehydrogenase for $\mathrm{DPNH}$ and glutathione reductase for TPNH. Recovery of added DPNH or TPNH to the cell extract was better than $95 \%$. Reduced glutathione (GSH) ${ }^{2}$ was measured by a minor modification of the method of Beutler, Duron, and Kelly (10) reacting, 5, $5^{\prime}$-dithiobis (2nitrobenzoic acid) with a neutralized perchloric acid extract

${ }^{2}$ It should be recognized that this method, although extensively employed for the measurement of GSH, is not specific for this compound and will measure any sulfhydrylreacting soluble peptide. However, as will be noted, the purpose of this measurement was to determine the relative "reductive capacity" of the cell sap in heavy vs. light platelets, rather than GSH specifically. 
TABLE IA

Embden-Meyerhof Pathway Enzymes

\begin{tabular}{|c|c|c|c|c|}
\hline Enzyme & Substrates & Auxilliary reagents* & Dilution & $\begin{array}{c}\text { Apparent } \\
K_{m}\end{array}$ \\
\hline Hexokinase & $\begin{array}{l}20 \mathrm{~mm} \text { glucose } \\
12 \mathrm{mM} \text { MgATP }\end{array}$ & $\begin{array}{l}\text { TPN+ } \\
\text { glucose-6-P } \\
\text { dehydrogenase }\end{array}$ & $1: 10$ & $\begin{array}{c}M \\
3.0 \times 10^{-5} \\
7.0 \times 10^{-4}\end{array}$ \\
\hline Phosphohexoisomerase & $10 \mathrm{~mm}$ fructose-6-P & $\begin{array}{l}\text { TPN+; B.S.A. } \\
\text { glucose-6-P } \\
\text { dehydrogenase }\end{array}$ & $1: 80$ & $7.7 \times 10^{-5}$ \\
\hline Phosphofructokinase & $\begin{array}{l}6 \mathrm{mM} \text { fructose-6-P } \\
1 \mathrm{mM} \text { MgATP }\end{array}$ & $\begin{array}{l}\text { DPNH; B.S.A. } \\
\text { Triose-P isomerase } \\
40 \mu \mathrm{g} / \mathrm{ml} \text { aldolase } \\
\alpha \text {-glycerol-P } \\
\text { dehydrogenase }\end{array}$ & $1: 20$ & $\begin{array}{l}5.7 \times 10^{-6} \\
5.0 \times 10^{-6}\end{array}$ \\
\hline Aldolase & $10 \mathrm{mM}$ fructose-1,6-diP & $\begin{array}{l}\text { DPNH } \\
\text { Triose-P isomerase } \\
\alpha \text {-glycerol-P } \\
\text { dehydrogenase }\end{array}$ & $1: 100$ & $2.5 \times 10^{-6}$ \\
\hline Triose- $\mathrm{P}$ isomerase & $2 \mathrm{mM}$ glyceraldehyde-3-P & $\begin{array}{l}\text { DPNH } \\
\alpha \text {-glycerol-P } \\
\text { dehydrogenase }\end{array}$ & $1: 200$ & $2.7 \times 10^{-4}$ \\
\hline $\begin{array}{l}\text { Glyceraldehyde-3-P } \\
\text { dehydrogenase }\end{array}$ & $\begin{array}{l}4 \mathrm{mM} \text { glyceraldehyde-3-P } \\
20 \mathrm{mM} \mathrm{Pi} \\
0.5 \mathrm{~mm} \mathrm{DPN}+\end{array}$ & & $1: 20$ & $\begin{array}{l}1.6 \times 10^{-5} \\
1.7 \times 10^{-4} \\
2.4 \times 10^{-5}\end{array}$ \\
\hline Phosphoglycerokinase & $\begin{array}{l}6 \mathrm{~mm} \text { 3-P-glycerate } \\
1 \mathrm{~mm} \mathrm{MgATP}\end{array}$ & $\begin{array}{l}\text { DPNH } \\
\text { glyceraldehyde-3-P } \\
\text { dehydrogenase }\end{array}$ & $1: 40$ & $\begin{array}{l}4.0 \times 10^{-5} \\
5.9 \times 10^{-6}\end{array}$ \\
\hline Phosphoglyceromutase & $\begin{array}{l}6 \mathrm{~mm} \text { 2-P-glycerate } \\
1 \mathrm{~mm} \text { MgATP }\end{array}$ & $\begin{array}{l}\text { DPNH } \\
\text { glyceraldehyde-3-P } \\
\text { dehydrogenase } \\
2 \mu \mathrm{g} / \mathrm{ml} \text { phosphoglycerokinase, } \\
50 \mathrm{mM} \mathrm{KCl}\end{array}$ & $1: 20$ & $\begin{array}{l}6.5 \times 10^{-5} \\
8.0 \times 10^{-5}\end{array}$ \\
\hline Enolase & $2 \mathrm{mM} 2 \mathrm{P}$-glycerate & $\begin{array}{l}\mathrm{DPNH} \\
2 \mathrm{mM} \mathrm{MgCl} \\
10 \mathrm{mM} \mathrm{MgADP} \\
2 \mu \mathrm{g} / \mathrm{ml} \text { pyruvate kinase } \\
\text { lactic dehydrogenase }\end{array}$ & $1: 100$ & $4.7 \times 10^{-5}$ \\
\hline Pyruvate kinase & $\begin{array}{l}5 \mathrm{mM} \text { P-enolpyruvate } \\
10 \mathrm{~mm} \mathrm{MgADP}\end{array}$ & $\begin{array}{l}\text { DPNH } \\
\text { lactic dehydrogenase }\end{array}$ & $1: 200$ & $\begin{array}{l}6.0 \times 10^{-4} \\
6.2 \times 10^{-4}\end{array}$ \\
\hline Lactic dehydrogenase & $\begin{array}{l}2 \mathrm{mM} \text { pyruvate } \\
0.3 \mathrm{mM} \text { DPNH }\end{array}$ & & $1: 200$ & $\begin{array}{l}3.6 \times 10^{-6} \\
4.6 \times 10^{-5}\end{array}$ \\
\hline
\end{tabular}

* All assays were run in tris buffer $50 \mathrm{mM}, \mathrm{pH} 7.5,5 \mathrm{mM}$ mercaptoethanol at $30^{\circ} \mathrm{C}$. Concentrations of auxilliary reagents consisted of : $0.5 \mathrm{mM}$ TPN $+; 0.3 \mathrm{mM}$ DPNH $; 4 \mathrm{mg} / \mathrm{ml}$ bovine serum albumin $; 2 \mu \mathrm{g} / \mathrm{ml}$ glucose- $6-\mathrm{P}$ dehydrogenase $; 4 \mu \mathrm{g} / \mathrm{ml}$ triose-P isomerase; $4 \mu \mathrm{g} / \mathrm{ml} \alpha$-glycerol-P dehydrogenase; $2 \mu \mathrm{g} / \mathrm{ml} \mathrm{glyceraldehyde-3-P} \mathrm{dehydrogenase;} 1 \mu \mathrm{g} / \mathrm{ml}$ lactic dehydrogenase. Pyruvate kinase rates were not appreciably affected by the addition of $10 \mathrm{mM} \mathrm{KCl}$.

obtained from a frozen platelet pellet (3). Recovery of added $\mathrm{GSH}$ to this extract was better than $95 \%$.

Lipid peroxidation. The oxidative degradation of unsaturated fatty acids was estimated by a product of lipid peroxidation recognized as malonyl dialdehyde (11-13). This was assayed by the 2-thiobarbitaric acid technique with final color development in alkaline solution (14). Clarification of "tissue" turbidity was achieved with the use of Bio-solv 
TABLE IB

Other Glycolytic and Related Enzymes*

\begin{tabular}{|c|c|c|c|c|}
\hline Enzyme & Substrates & Auxilliary reagents & Dilution & $\underset{K_{m}}{\text { Apparent }}$ \\
\hline Phosphoglucomutase & $10 \mathrm{~mm}$ glucose-1-P & $\begin{array}{l}\mathrm{TPN}^{+} ; \mathrm{B} . \mathrm{S} . \mathrm{A} . \\
\text { Glucose-6-P dehydrogenase } \\
1 \mathrm{mM} \mathrm{MgCl}\end{array}$ & $1: 20$ & $3.5 \times 10^{-5}$ \\
\hline $\begin{array}{l}\text { Glucose-6-P } \\
\text { dehydrogenase }\end{array}$ & $\begin{array}{l}10 \mathrm{~mm} \text { glucose-6-P } \\
0.5 \mathrm{~mm} \text { TPN }+\end{array}$ & & $1: 20$ & $\begin{array}{l}7.7 \times 10^{-5} \\
2.8 \times 10^{-5}\end{array}$ \\
\hline $\begin{array}{l}\text { 6-P-gluconic } \\
\text { dehydrogenase }\end{array}$ & $\begin{array}{l}10 \mathrm{~mm} \text { 6-P-gluconate } \\
0.5 \mathrm{~mm} \mathrm{TPN}+\end{array}$ & $1 \mathrm{~mm} \mathrm{MgCl}$ & $1: 10$ & $\begin{array}{l}2.7 \times 10^{-5} \\
8.2 \times 10^{-6}\end{array}$ \\
\hline $\begin{array}{l}\alpha-\text {-Glycerol-P } \\
\text { dehydrogenase }\end{array}$ & $\begin{array}{l}5 \mathrm{~mm} \text { dihydroxyacetone-P } \\
0.3 \mathrm{~mm} \text { DPNH }\end{array}$ & & $1: 5$ & $\begin{array}{l}3.0 \times 10^{-5} \\
2.2 \times 10^{-6}\end{array}$ \\
\hline $\begin{array}{l}\text { Glutathione } \\
\text { reductase }\end{array}$ & $\begin{array}{l}10 \mathrm{~mm} \text { GSSG } \\
0.3 \mathrm{~mm} \text { TPNH }\end{array}$ & & $1: 4$ & $\begin{array}{l}6.1 \times 10^{-3} \\
2.3 \times 10^{-5}\end{array}$ \\
\hline
\end{tabular}

* All assays were run in tris buffer $50 \mathrm{mM}, 5 \mathrm{~mm}$ mercaptoethanol, $\mathrm{pH} 7.5$ at $30^{\circ} \mathrm{C}$. Concentrations of auxilliary reagents consisted of : $0.5 \mathrm{mM} \mathrm{TPN}^{+} ; 4 \mathrm{mg} / \mathrm{ml}$ B.S.A.; $2 \mu \mathrm{g} / \mathrm{ml}$ glucose-6-P dehydrogenase.

Both phosphoglucomutase and 6-P-gluconic dehydrogenase had suboptimal rates in the absence of $\mathrm{Mg}++$ which increased 12-fold and 3.3-fold, respectively, in the presence of $1 \mathrm{mM} \mathrm{MgCl}$. Phosphoglucomutase rates were not affected by the addition of $0.2 \mathrm{~mm}$ glucose-1,6-diphosphate. Glutathione reductase rates were inhibited by the addition of 0.004-0.4 mM FAD.

(15). A standard curve was obtained with malonyl dialdehyde bis(diethylacetal). Products of lipid peroxidation were enhanced by the use of $\mathrm{FeCl}_{3}$ as catalyst (16). A $0.5 \%$ vol suspension of washed platelets was incubated for $1 \mathrm{hr}$ at $37^{\circ} \mathrm{C}$ in the presence and absence of $0.1 \mathrm{~mm} \mathrm{FeCl}_{3}$. These conditions were found to be optimum for formation of products of lipid peroxidation.

Protein measurement. Protein was measured by the Biuret method (17), employing salt-free bovine serum albumin as standard. No significant difference was noted in the protein content of the $105,000 \mathrm{~g}$ supernate when either extraction procedure was employed (four experiments). The heavy platelet population, $105,000 \mathrm{~g}$ supernate, contained $22 \%$ more protein than the light population with both extraction procedures, i.e., 16.5 vs. $13.5 \mathrm{mg} / \mathrm{ml}$ (eight experiments, $P<0.01)$. This small difference in protein content was similar to that reported previously (4).

Incubation experiments. Heavy platelets were resuspened in their own (ACD-A) plasma (previously gassed with $5 \%$ $\mathrm{CO}_{2}-95 \% \mathrm{O}_{2}$ ) and incubated for $17 \mathrm{hr}$ at $37^{\circ} \mathrm{C}$ as a $0.5 \mathrm{vol}$ per cent (physiologic) platelet suspension in the presence of penicillin, $100 \mathrm{U} / \mathrm{ml}$, and additional glucose of $150 \mathrm{mg} / \mathrm{ml}$. The $\mathrm{pH}$ of the incubation mixture remained fairly constant at about $\mathrm{pH} 7$.

Measurement of platelet volume and relative population volume. Platelets were enumerated via phase microscopy as described previously (5). Platelet volume was determined by centrifugation at $2000 \mathrm{~g}$ in $12.5-\mathrm{cm}$ glass capillary tubes, (obtained from Clay Adams, Parsippany, N. J.) as described previously (2). The relative volume difference between heavy and light platelet populations was obtained by dividing the number of platelets per packed cell volume of light platelets by the number of platelets per packed cell volume of heavy platelets. The average volume of heavy platelets was approximately twice that of light platelets, with a range of 2- to 2.4-fold. Extracellular space measurements of the packed cell volumes of washed heavy, total, and light platelets were determined with inulin $\left({ }^{14} \mathrm{C}\right)$ and revealed no significant difference between populations. Extracellular space averaged $12.2 \pm 2.1 \%$ (SD, eight experiments). Radioactivity was measured in a Beckman LS 100 scintillation spectrometer with isoset adjusted to give $96 \%$ counting efficiency. Platelets were dissolved in $0.5 \mathrm{ml}$ of Hyamine hydroxide and quantitatively transferred to a scintillation cocktail. Control experiments revealed no interference in radioactivity measurements by platelet concentrations employed in the determination of extracellular space. Counts per minute were 5-100 times background and counting error was adjusted to less than $3 \%$.

$K_{m}$ measurements. Apparent $K_{m}$ were measured with dilutions of tissue extract $(105,000 \mathrm{~g}$ supernate) which varied from 200 - to 10,000 -fold. It is very unlikely, therefore that any significant interference could have been encountered from tissue glycolytic intermediates or other products. Six substrate concentrations were employed to determine velocity measurements for the apparent $K_{m}$ measurement. Lineweaver-Burke plots were linear for all enzymes measured except for glutathione reductase (TPNH), $\alpha$-glycerol-P dehydrogenase (dihydroxyacetone-P), and phosfructokinase (MgATP) where nonlinearity was noted at high substrate concentration. These $K_{m}$ were measured at the cosubstrate concentration designated in Table $I$.

Empirical $V_{\max }$. This was the highest enzyme rate obtained with increasing substrate concentration when cosubstrate concentration (when indicated) was held at the concentration cited in Table IA and B.

Materials. Distilled deionized water was used at all times. All chemicals were reagent grade. Enzyme reagents were obtained from either Sigma Chemical Co., St. Louis, Mo., or Boehringer Mannheim Corp., New York unless otherwise 
indicated. Beef heart lactic dehydrogenase was obtained from Worthington Biochemical Corp., Freehold, N. J. N-dibutyl phthalate was obtained from Fisher Scientific Co., Pittsburgh, Pa. Apiezon A oil was obtained from James G. Biddle Co., Plymouth Meeting, Pa. Hyamine hydroxide was obtained from Packard Instrument Co., Inc., Downers Grove, Ill. Dithiothreitol was obtained from Calbiochem, San Diego, Calif. Mercaptoethanol was obtained from Eastman Organic Chemicals Div., Eastman Kodak Co., Rochester, N. Y. 5,5dithiobis(2-nitrobenzoic acid) was obtained from Sigma Chemical Co. Bio-solv was obtained from Beckman Instruments Inc., Fullerton, Calif. Malonyl dialdehyde bis (diethylacetal) was obtained from J. T. Baker Chemical Co., Phillipsburg, N. J. Chloroquine hydrochloride was obtained from Winthrop Laboratories, New York. Cortisone acetate was obtained from Merck \& Co., Inc., Rahway, N. J., (carboxylic ${ }^{14} \mathrm{C}$ ) inulin, $8.3 \mathrm{mCi} / \mathrm{mm}$, was obtained from Nuclear-Chicago Corp., Des Plaines, Ill.

\section{RESULTS}

\section{Enzyme measurements of the total platelet population}

Optimum enzyme activity was dependent upon the extraction procedure employed and the duration of time between extraction and assay of enzyme rate (see Methods). The sonic lysate extraction procedure gave highest rates for most of the enzymes measured, the exceptions being glucose-6-P dehydrogenase, 6-P-gluconic dehydrogenase, and lactic dehydrogenase. Higher rates were obtained for these three enzymes with the freeze-grinding procedure (1.8, 1.2, and 1.3-fold higher respectively, $>2$ sD difference). The empirical $\mathrm{V}_{\max }$ with \pm SD range is reported for the extraction procedure giving the highest rate. These experiments represent the mean of 8-10 different determinations from platelet

TABLE II

Enzyme Activity of Total Platelet Population Cell Sap

\begin{tabular}{lcc}
\hline Embden-Meyerhof pathway enzymes & Mean $V_{\max } *$ & Range \pm 2 sD \\
\hline Hexokinase & 200 & $172-228$ \\
Phosphohexoisomerase & 3202 & $2922-3482$ \\
Phosphofructokinase & 552 & $422-682$ \\
Aldolase & 913 & $685-1141$ \\
Triose-P isomerase & 8152 & $7532-8772$ \\
Glyceraldehyde-3-P dehydrogenase & 499 & $415-583$ \\
Phosphoglycerokinase & 1592 & $1458-1726$ \\
Phosphoglyceromutase & 733 & $625-841$ \\
Enolase & 6230 & $5621-6839$ \\
Pyruvate kinase & 4019 & $3163-4875$ \\
Lactic dehydrogenaseł & 4397 & $3797-4997$ \\
Other related enzymes & & \\
Phosphoglucomutase & 550 & $504-596$ \\
Glucose-6-P dehydrogenase & 579 & $556-602$ \\
6-P-gluconic dehydrogenase & 295 & $272-318$ \\
$\alpha$-Glycerol-P dehydrogenase & 15 & $12-19$ \\
Glutathione reductase & 161 & $139-183$ \\
\hline
\end{tabular}

* Micromoles/gram wet weight per hour at $30^{\circ} \mathrm{C}$.

¥ Extracted by freeze-grind method; other enzymes extracted by sonic lysate method.
TABLE III

Platelet Population Enzyme Activity*

\begin{tabular}{lrrrr}
\hline $\begin{array}{l}\text { Embden-Meyerhof } \\
\text { pathway enzymes }\end{array}$ & Light & Total & Heavy & $\begin{array}{c}\text { Heavy/light } \\
\text { ratio }\end{array}$ \\
\hline Hexokinase & 128 & 200 & 239 & 1.9 \\
Phosphohexoisomerase & 2310 & 3202 & 4577 & 2.1 \\
Phosphofructokinase & 411 & 552 & 801 & 2.0 \\
Aldolase & 1008 & 913 & 1008 & 1.0 \\
Triose-P isomerase & 7860 & 8152 & 7860 & 1.0 \\
Glyceraldehyde-3-P dehydrogenase & 357 & 499 & 709 & 2.0 \\
Phosphoglycerokinase & 894 & 1592 & 1619 & 1.8 \\
Phosphoglyceromutase & 688 & 733 & 708 & 1.0 \\
Enolase & 6560 & 6230 & 6410 & 1.0 \\
Pyruvate kinase & 5510 & 4019 & 5568 & 1.0 \\
Lactic dehydrogenase & 3010 & 4397 & 6260 & 2.1 \\
Other related enzymes & & & & \\
Phosphoglucomutase & & & & \\
Glucose-6-P dehydrogenase & 600 & 579 & 630 & 1.1 \\
6-P-gluconic dehydrogenase & 308 & 295 & 322 & 1.0 \\
$\alpha-$ glycerol-P dehydrogenase & 15 & 15 & 17 & 1.1 \\
Glutathione reductase & 152 & 161 & 161 & 1.1 \\
\hline
\end{tabular}

* Micromoles/gram wet weight per hour at $30^{\circ} \mathrm{C}$.

pools obtained from $2-4$ different $U$ of platelet-rich plasma, Table II. The three apparent "rate-limiting enzymes" of the Embden-Meyerhof pathway (i.e., enzymes with lowest activity) were hexokinase, phosphofructokinase, and glyceraldehyde-3-P dehydrogenase.

Cellular distribution of enzyme activity. The $4000 \mathrm{~g}$ homogenate rates equaled the sum $\pm 10 \%$ of the 105 ,$000 \mathrm{~g}$ supernatant and sediment rates for all the enzymes measured. The $105,000 \mathrm{~g}$ supernatant rates represented approximately $97-100 \%$ of total enzyme activity for 13 of the 16 enzymes measured. Three of the enzymes measured had significant particulate enzyme rates, with both extraction procedures which represented $10 \%$ or more of the total enzyme activity. These were hexokinase $(8.0-10.7 \%), \alpha$-glycerol-P dehydrogenase (16.9$23.2 \%)$, and glutathione reductase $(12.5-12.5 \%)$. Values given are the mean of three experiments for freeze-grind and sonic lysate procedures, respectively.

\section{Comparison of heavy, light, and total platelet populations}

6 of the 11 Embden-Meyerhof pathway enzymes: hexokinase, phosphohexoisomerase, phosphofructokinase, glyceraldehyde-3-P dehydrogenase, phosphoglycerokinase, and lactic dehydrogenase were present at an approximately twofold greater activity in heavy platelets compared with light platelets, Table III and Fig. 1. Similar results were obtained for one of the other five enzymes measured, phosphoglucomutase, Table III.

Fig. 1 compares the empirical $V_{\max }$ of the total platelet population with the ratio in $\mathrm{V}_{\max }$ between the heavy and light platelet populations. It is of interest that the three "rate limiting" enzymes mentioned above are 


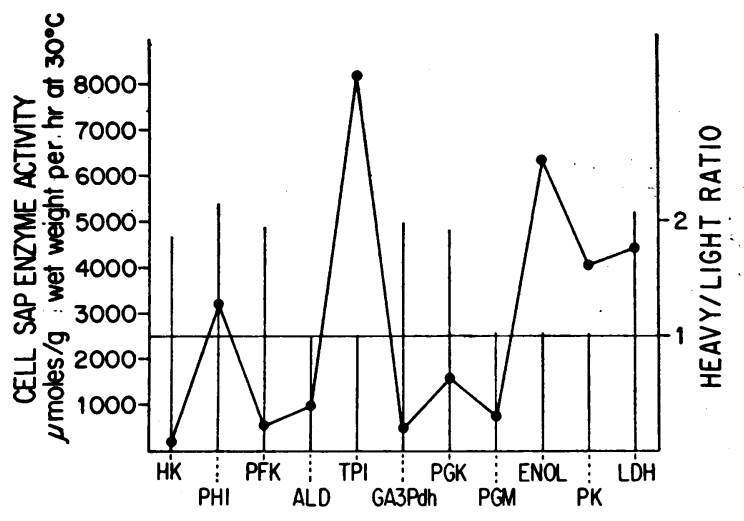

FIGURE 1 Empirical $V_{\max }$ of enzymes of the Embden-Meyerhof pathway. Data for total platelet population ( -0$)$ are compared with the ratio of $\mathrm{V}_{\max }$ of enzymes of heavy platelets and light platelets (vertical lines). Rates are given as micromoles/gram wet weight per $\mathrm{hr}$ at $30^{\circ} \mathrm{C}$ and represent the average of 8-10 experiments.

among the enzymes with twofold greater activity in heavy than in light platelets.

\section{In vitro incubation of heavy platelets}

Effect on empirical $V_{\max }$. Washed heavy platelets were incubated in their own plasma at $37^{\circ} \mathrm{C}$ (see Methods) in order to compare in vitro lability of the enzymes measured with in vivo differences between heavy and light platelets (i.e., heavy and light platelets extracted at time zero). Fig. 2 reveals the pattern of enzyme decay for all 11 Embden-Meyerhof pathway enzymes. The basal heavy/light ratio is given in parentheses. As can be noted, the group of six enzymes with twice the activity in heavy vs. light platelets, are the enzymes which are more labile when heavy plate-

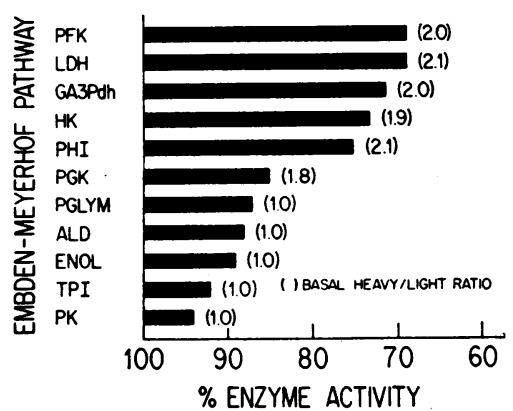

FIGURE 2 In vitro incubation of heavy platelets for $17 \mathrm{hr}$. Empirical $\mathrm{V}_{\max }$ was measured at zero time and after $17 \mathrm{hr}$ of sterile incubation in plasma with 0.5 vol per cent platelet suspension. Per cent remaining enzyme activity is compared with initial heavy/light ratio. Data represent the average of four incubation experiments.

lets are incubated in vitro at $37^{\circ} \mathrm{C}$ for $17 \mathrm{hr}$. The same also applied for phosphoglucomutase of the other enzyme group. Similar results were obtained after 40 $\mathrm{hr}$ of in vitro incubation (four experiments).

\section{Studies on the mechanism of increased enzyme lability in vitro}

Possible release of intracellular enzymes into plasma. The increased lability of this group of seven enzymes could not be attributed to disruption of platelets with release of enzymes into the plasma, since plasma enzyme activity before and after incubation represented less than $1 \%$ of total platelet activity at time zero (average of three experiments). It is possible however, that "released" plasma enzymes may have been inactivated during the period of incubation.

Possible release of lysosomal enzymes. The increased

TABLE IV

Effect of Cortisone Acetate, Chloroquine Hydrochloride, Dithiothreitol, GSH, or Ascorbic Acid on In Vitro Enzyme Lability of Heavy Platelets after Incubation at $37^{\circ} \mathrm{C}$ for $17 \mathrm{Hr}$

\begin{tabular}{|c|c|c|c|c|c|c|c|}
\hline Enzymes & $\begin{array}{l}\text { Control* } \\
(4)\end{array}$ & $\begin{array}{l}\text { Cortisone } \\
\text { (2) }\end{array}$ & $\begin{array}{l}\text { Chloroquine } \\
\text { (1) }\end{array}$ & $\begin{array}{l}\text { Dithiothreitol } \\
\text { (3) }\end{array}$ & $\begin{array}{l}\text { GSH } \\
\text { (2) }\end{array}$ & $\begin{array}{c}\text { Ascorbic acid } \\
\text { (2) }\end{array}$ & $\begin{array}{c}\text { GSH } \\
+ \\
\text { ascorbic acid } \\
\text { (2) }\end{array}$ \\
\hline Hexokinase & 73 & 58 & 64 & 123 & 75 & 91 & 89 \\
\hline Phosphohexoisomerase & 75 & 68 & 64 & 109 & 100 & 85 & 104 \\
\hline Phosphofructokinase & 69 & 57 & 58 & 126 & 74 & 87 & 79 \\
\hline \multicolumn{8}{|l|}{ Glyceraldehyde-3-P } \\
\hline dehydrogenase & 71 & 61 & 58 & 107 & 80 & 77 & 84 \\
\hline Phosphoglycerokinase & 85 & 73 & 63 & 101 & 112 & 104 & 104 \\
\hline Lactic dehydrogenase & 69 & 60 & 48 & 82 & 94 & 89 & 88 \\
\hline Phosphoglucomutase & 76 & 65 & 62 & 119 & 81 & 79 & 86 \\
\hline
\end{tabular}

* Per cent of initial enzyme activity after $17 \mathrm{hr}$ incubation at $37^{\circ} \mathrm{C}$ in plasma, $100 \mathrm{U} / \mathrm{ml}$ penicillin, and additional $150 \mathrm{mg} / \mathrm{ml}$ glucose. Number of experiments is given in parentheses. Concentration of effector agents: cortisone acetate, $10^{-4} \mathrm{M}$ : chloroquine hydrochloride, $10^{-4} \mathrm{M}$; dithiothreitol, $10^{-5} \mathrm{M}$; GSH, $10^{-8} \mathrm{M}$; ascorbic acid, $10^{-3} \mathrm{M}$. 
lability could not be attributed to intracellular release of lysosomal enzymes, since addition of lysosomal stabilizers (18), such as cortisone acetate or chloroquine hydrochloride had no beneficial effect on the lability of this group of seven enzymes, Table IV.

Evidence for oxidative stress during in vitro incubation. However, addition of reducing agents such as dithiothreitol, GSH, or ascorbic acid were successful in preventing the decay of enzyme activity noted at the end of $17 \mathrm{hr}$ of in vitro incubation at $37^{\circ} \mathrm{C}$, Table IV. Dithiothreitol at $10^{-8} \mathrm{M}$ was the most effective agent employed.

Intracellular reductive capacity of platelets. The cellular reductive capacity of heavy, total, and light platelet populations were next examined by measurement of the intracellular reducing agents: GSH, DP$\mathrm{NH}$, and TPNH, at zero time and after in vitro incubation at $37^{\circ} \mathrm{C}$. Table $\mathrm{V}$ reveals a greater content of GSH, DPNH, and TPNH in heavy platelets compared with light platelets of 1.9, 1.7, and 1.2-fold respectively $(P<0.01)$. After in vitro incubation of heavy platelets at $37^{\circ} \mathrm{C}(1 \mathrm{hr}$ for $\mathrm{GSH}$ and $17 \mathrm{hr}$ for DPNH and TPNH), GSH, DPNH, and TPNH declined 41,26 , and $10 \%$ respectively $(P<0.01)$.

Lipid peroxidation products and resistance to lipid peroxidation. A 1.8-fold greater content of lipid peroxidation products was noted in light platelets compared with heavy platelets (Table V). After incubation for $17 \mathrm{hr}$ at $37^{\circ} \mathrm{C}$ heavy platelet lipid peroxidation products increased 1.8-fold (Table V). When exposed

\section{TABLE V}

Reductive Capacity and Resistance to Lipid Peroxidation of Different Platelet Populations

\begin{tabular}{|c|c|c|c|c|c|}
\hline & Heavy & Total & Light & $\begin{array}{c}\text { Heavy/lightf } \\
\text { ratio }\end{array}$ & $\begin{array}{c}\text { Heavy } \\
\text { incubation }\end{array}$ \\
\hline GSH (5)* & 10.2 & 7.20 & 5.42 & 1.9 & 6.29 \\
\hline DPNH (4) & 0.049 & 0.035 & 0.029 & 1.7 & 0.036 \\
\hline \multirow[t]{2}{*}{ TPNH (4) } & 0.069 & 0.063 & 0.057 & 1.2 & 0.062 \\
\hline & & & & $\begin{array}{c}\text { Light/heavy } \\
\text { ratio }\end{array}$ & \\
\hline Lipid Perox. (4)\| & 2.19 & & 3.95 & 1.8 & 3.85 \\
\hline$+\mathrm{FeCl}_{2}(5)$ & 5.39 & & 12.94 & 2.4 & \\
\hline
\end{tabular}

* Micromoles/gram wet weight of initially extracted GSH, DPNH, and TPNH of various platelet populations; number of experiments given in parentheses.

$\ddagger$ Probability of heavy/light ratio being greater than 1 was significant at the $P<0.01$ level. SEM was less than $10 \%$.

Heavy platelets were suspended in plasma ( 0.5 vol per cent) and incubated for $1 \mathrm{hr}$ (GSH) or $17 \mathrm{hr}$ (DPNH, TPNH, lipid peroxidation) at $37^{\circ} \mathrm{C}$, before extraction.

II Nanomoles/gram wet weight of malonyl dialydehyde equivalents. Washed platelets were initially extracted; or suspended in human Ringer solution $(0.5 \%$ vol) containing $0.1 \mathrm{mM} \mathrm{FeCl}$ and incubated for $1 \mathrm{hr}$ at $37^{\circ} \mathrm{C}$ before extraction; number of experiments given in parentheses.

I Probability of light/heavy ratio being greater than 1 was significant at the $P<0.01$ level. SEM was less than $10 \%$. to the oxidative catalytic action of $\mathrm{FeCl}_{8}$, heavy platelets were 2.4-fold more resistant to the formation of lipid peroxidation products than were light platelets (Table V).

\section{DISCUSSION}

These data reveal the heterogeneity of human platelets with respect to glycolytic and other enzyme activity; and with respect to reductive capacity and ability to resist oxidative stress. They are consistent with previously reported data on the heterogeneity of human platelet glycogenolysis, glycolysis, adenine nucleotide content, and resistance to osmotic shock (maintenance of cationic gradients [4]). They lend support to previously reported data on enhanced glycogen synthetase and fructose-1,6-diphosphatase activity of heavy platelets with associated increased glycogen content, glycogenesis, and glyconeogenesis (5). Thus heavy platelets are more active metabolically, have a greater reductive capacity and are more resistant to "oxidative" stress than light platelets. This cannot be attributed to the increased platelet volume of heavy platelets since these differences are obtained from data expressed per gram wet weight or per unit volume (or milligram protein).

The three "rate-limiting" glycolytic enzymes: hexokinase, phosphofructokinase, and glyceraldehyde-3-Pdehydrogenase ("sulfhydryl-dependent" enzymes) were found to be present at twofold the activity in heavy platelets compared with light platelets. The group of enzymes with greater activity was also found to be more "labile" after simulated in vivo conditions i.e., in vitro incubation in plasma at $37^{\circ} \mathrm{C}$ for $17 \mathrm{hr}$. Similar results were obtained at $40 \mathrm{hr}$ of incubation. The mechanism of the increased lability is apparently related to oxidative processes within the cell or on the membrane, since reducing agents can partially or completely reverse this effect in heavy platelets. This is consistent with the increased resistance to lipid peroxidation in heavy platelets. It is conceivable that free radical formation might be responsible for the oxidative changes noted during in vitro incubation of heavy platelets; as well as partially responsible for the enzyme differences noted in "initially extracted" heavy and light platelets. Differences in enzyme activity might also be related to the greater reductive capacity and resistance to lipid peroxidation of heavy platelets compared with light platelets. Free radical formation is further supported by the apparent increase in lipid peroxidation after incubation of heavy platelets, associated with a decrease in enzyme activity. Lipid peroxides and their products have been shown to be metabolic poisons capable of forming inactivating complexes with proteins $(19,20)$ and essential enzymes (21-23). Oxidation of sulfhydryl groups $(20,22)$, microsomes, mitochondria (24-27), 
and swelling and lysis of mitochondria (27) have been reported secondary to lipid peroxidation. Indeed free radical formation has been incriminated as one of the mechanisms responsible for the process of aging (28, 29).

If lability of rate-limiting glycolytic and other enzymes secondary to oxidative stress is associated with in vitro platelet senescence, it might also be associated with in vivo senescence. In this context, increased resistance to lipid peroxidation has recently been reported in "young" rat platelets obtained after the administration of rabbit anti-rat platelet antibody (15). Furthermore, Murphy and Gardner (30) have recently presented evidence, from platelet preservation studies, that in vitro aging approximates in vivo aging. It should be emphasized, however, that the association of ratelimiting enzyme lability with in vitro incubation and oxidative stress does not prove a causal relationship.

Previous cellular kinetic data in rabbits and humans have suggested a transition of the heavy large, young platelet to a lighter smaller, older platelet $(4,7)$. McDonald, Odell, and Goslee (31) have noted a decrease in rat platelet size with aging. Minter and Ingram (32) have noted an increase in dog platelet size and density after the thrombopoietic stimulus of acute blood loss. In a more recent publication, Minter and Ingram (33) have referred to the heavy large platelets of acute blood loss in dogs as young "stress" platelets, rather than "physiologic" young platelets. Their evidence, although indirect, does not support a transition of heavy large "stress" platelets to lighter smaller platelets. The heavy large platelets in our study were isolated during basal conditions and not obtained under thrombopoietic stress. It is conceivable that two types of heavy large platelets apply: one that is physiologically young, the other that is "stress" young.

If heavy large young platelets do indeed become lighter smaller older platelets as has been suggested $(4,7,31)$ it would be tempting to speculate that this could occur as a result of, or associated with, loss of glycolytic "rate-limiting" enzyme activity. This in turn would contribute to lower energy stores, i.e., glycogen and adenine nucleotide content. The platelet, being an aerobic glycolytic tissue is dependent to a large extent upon the Embden-Meyerhof pathway for its energy requirement (1-3). This energy is required for the maintenance of cationic gradients (34), maintenance of steady-state conditions (3), and maintenance of platelet discoid shape $(3,35)$. Consequently, any impairment in energy storage or utilization would be a decided disadvantage to the cell with respect to viability. Energy is also required for platelet function: ADPinduced platelet-plug formation (36), clot retraction (36), incorporation of $\mathrm{P}^{32}$ into phospholipid (37) and phospholipid synthesis (38), active transport of amino acids (39) and serotonin (40).

The presently reported biochemical data on glycolytic enzymes, reductive capacity, and resistance to oxidative stress of different platelet populations indicate the metabolic heterogeneity of human platelets and lend indirect support to the concept of human platelet senescence.

\section{ACKNOWLEDGMENTS}

This study was supported by grants from the National Institutes of Health (HE 13336-02) and the New York Heart Association, and by contract DADA17-68-C-8163 of the U. S. Army Research and Development Command.

\section{REFERENCES}

1. Luganova, I. S., I. F. Seits, and V. I. Teodorovich. 1958. Metabolism in human thrombocytes. Biokhimiya. 23: 379.

2. Karpatkin, S. 1967. Studies on human platelet glycolysis. Effect of glucose, cyanide, insulin, citrate, and agglutination and contraction on platelet glycolysis. $J$. Clin. Invest. 46: 409.

3. Karpatkin, S., and R. M. Langer. 1968. Biochemical energetics of simulated platelet plug formation. Effect of thrombin, adenosine diphosphate and epinephrine on intra- and extracellular adenine nucleotide kinetics. $J$. Clin. Invest. $47: 2158$.

4. Karpatkin, S. 1969. Heterogeneity of human platelets. I. Metabolic and kinetic evidence suggestive of young and old platelets. J. Clin. Invest. 48: 1073.

5. Karpatkin, S., and A. Charmatz. 1970. Heterogeneity of human platelets. III. Glycogen metabolism in platelets of different sizes. Brit. J. Haematol. 19: 135.

6. Karpatkin, S. 1969. Heterogeneity of human platelets. II. Functional evidence suggestive of young and old platelets. J. Clin. Invest. 48: 1083.

7. Amorosi, E. L., S. K. Garg, and S. Karpatkin. 1971. Heterogeneity of human platelets. IV. Identification of a young platelet population with $\mathrm{Se}^{\mathrm{Ts}}$-selenomethione. Brit. J. Haematol. 21 : 227.

8. Lyman, B., L. Rosenberg, and S. Karpatkin. 1971. Biochemical and biophysical aspects of human platelet adhesion to collagen fibers. J. Clin. Invest. 50: 1854.

9. Ciotti, M. M., and N. O. Kaplan. 1957. Procedures for determination of pyridine nucleotides. Methods Enzymol. 3 : 890.

10. Beutler, E., O. Duron, and B. M. Kelly. 1963. Improved method for the determination of blood glutathione. J. Lab. Clin. Med. 61: 882 .

11. Kohn, H., and M. Liversedge. 1944. On a new aerobic metabolite whose production by brain is inhibited by amorphine, ergotamine, epinephrine, and menadione. $J$. Pharmacol. Exp. Ther. $82: 292$.

12. Bernheim, F., M. Bernheim, and K. Wilbur. 1947. The reaction between thiobarbituric acid and the oxidation products of certain lipids. J. Biol. Chem. 174: 257.

13. Patton, S., and G. Kurtz. 1951. 2-Thiobarbituric acid as a reagent for detecting milk fat oxidation. J. Dairy Sci. 34: 669 .

14. Placer, Z. A., L. L. Cushman, and B. C. Johnson. 1966. Estimation of product of lipid peroxidation (malonyl dialdehyde) in biochemical systems. Anal. Biochem. 16: 359. 
15. Okuma, M., M. Steiner, and M. Baldini. 1969. Lipid peroxidation in aging platelets. Blood. $34: 712$.

16. Smith, G. J., and W. L. Dunkley. 1962. Initiation of lipid peroxidation by a reduced metal ion. Arch. Biochem. Biophys. 98 : 46.

17. Dittebrandt, M. 1961. In Experimental Immunochemistry. E. Kabat, and M. M. Mayer, editors. Charles C. Thomas, Publishers, Springfield, Ill. 2nd edition. 559.

18. Weissman, G. 1969. The effects of steroids and drugs on lysosomes. In Lysosomes in Biology and Pathology. J. T. Dingle and H. B. Fell, editors. North Holland Publishing Co., Amsterdam. 276.

19. Lewis, S. E., and E. D. Wills. 1962. The destruction of $-\mathrm{SH}$ groups of proteins and amino acids by peroxides of unsaturated fatty acids. Biochem. Pharmacol. 11: 901.

20. Desai, I. D., and A. L. Tappel. 1963. Damage to proteins by peroxidized lipids. J. Lipid Res. 4: 204.

21. Bernheim, F., K. M. Wilbur, and C. B. Kenaston. 1952. The effect of oxidized fatty acids on the activity of certain oxidative enzymes. Arch. Biochem. 38: 177.

22. Wills, E. D. 1961. Effect of unsaturated fatty acids and their peroxides on enzymes. Biochem. Pharmacol. $7: 7$.

23. Malley, B. W., C. E. Mengel, W. D. Meriwether, and L. G. Zirkle, Jr. 1966. Inhibition of erythrocyte acetylcholinesterase by peroxides. Biochemistry. 5: 40.

24. Slater, T. F. 1968. The inhibitory effects in vitro of phenothiazines and other drugs on lipid-peroxidation systems in rat liver microsomes, and their relationship to the liver necrosis produced by carbon tetrachloride. Biochem. J. 106: 155.

25. Hochstein, P., and L. Ernster. 1963. ADP-activated lipid peroxidation coupled to the TPNH oxidase system of microsomes. Biochem. Biophys. Res. Commun. $12: 388$.

26. Wills, E. D. 1965. Mechanism of lipid peroxide formation in tissues. Role of metals and haematin proteins in the catalysis of the oxidation of unsaturated fatty acids. Biochim. Biophys. Acta. 98: 238.

27. Hunter, F. E., A. Scott, P. E. Hoffsten, J. M. Gebicki, J. Weinstein, and A. Schneider. 1964. Studies on the mechanism of swelling, lysis, and disintegration of iso- lated liver mitochondria exposed to mixtures of oxidized and reduced glutathione. J. Biol. Chem. 239: 614.

28. Dormandy, T. L. 1969. Biological rancidification. Lancet. 2: 684.

29. Pryor, W. A. 1970. Free radicals in biological systems. Sci. Amer. $223: 70$.

30. Murphy, S., and F. H. Gardner. 1969. Platelet preservation: effect of storage temperature on maintenance of platelet viability-deleterious effect of refrigerated storage. N. Engl. J. Med. 280: 1094.

31. McDonald, T. P., T. T. Odell, Jr., and D. G. Goslee. 1964. Platelet size in relation to platelet age. Proc. Soc. Exp. Biol. Med. 115 : 684 .

32. Minter, F. M., and M. Ingram. 1967. Density distribution of platelets. Blood. 30: 551 .

33. Minter, F. M., and M. Ingram. 1971. Platelet volume: density relationships in normal and acutely bled dogs. Brit. J. Haematol. 20 : 55.

34. Gorstein, F., H. J. Carroll, and E. Puszkin. 1967. Electrolyte concentrations, potassium flux kinetics, and the metabolic dependence of potassium transport in human platelets. J. Lab. Clin. Med. 70: 938.

35. Bull, B. S., and M. B. Zucker. 1965. Changes in platelet volume produced by temperature, metabolic inhibitors, and aggregating agents. Proc. Soc. Exp. Biol. Med. 120: 296.

36. Murer, E. H., A. J. Hellem, and M. C. Rozenberg. 1967. Energy metabolism and platelet function. Scand. J. Clin. Lab. Invest. 19: 280.

37. Grossman, C. M., and R. Kohn. 1965. Enzymatic characteristics of in vitro incorporation of $\mathrm{P}^{\mathrm{s}}$ orthophosphate into human platelet phosphatide. Thromb. Diath. Haemorrh. 13 : 126.

38. Lewis, N., and P. W. Majerus. 1969. Lipid metabolism in human platelets. II. De novo synthesis and the effect of thrombin on the patterns of synthesis. $J$. Clin. Invest. $48: 2114$.

39. Zieve, P. D., and H. M. Solomon. 1968. Uptake of amino acids by the human platelet. Amer. J. Physiol. $214: 58$.

40. Born, G. V. R., and R. E. Gillson. 1959. Studies on the uptake of 5-hydroxytryptamine by blood platelets. J. Physiol. (London). 146: 472. 